\title{
TGF- $\beta 1$ Induces Epithelial-Mesenchymal Transition of Chronic Sinusitis with Nasal Polyps through MicroRNA-21
}

\author{
Xun Li Chuang Li Ganghua Zhu Wenhui Yuan Zi-an Xiao \\ Department of Otolaryngology, Head and Neck Surgery, Second Xiangya Hospital, Central South University, \\ Changsha, PR China
}

\section{Keywords}

Chronic rhinosinusitis with nasal polyps - MicroRNA-21 .

Epithelial-mesenchymal transition · PTEN/Akt · TGF- $\beta 1$

\begin{abstract}
Objectives: To characterize the epithelial-mesenchymal transition (EMT) in chronic rhinosinusitis with nasal polyps (CRSwNP) and to investigate the mechanism by which microRNA-21 (miR-21) regulates EMT in CRSwNP. Method: (1) Tissue experiments: Mucosa tissues were collected from 13 patients with CRSwNP and 12 patients with CRS without nasal polyps (CRSsNP), as well as 11 patients without CRS (controls). Protein localization and quantification were achieved by immunofluorescence staining and Western blotting, involving the epithelial marker protein E-cadherin and the mesenchymal marker proteins a-smooth muscle actin (a-SMA), fibronectin, and vimentin. Quantitative RT-PCR was used to detect the relative expression levels of miR-21 and TGF- $\beta 1$ mRNAs. (2) Cellular experiments: Primary human nasal epithelial cells (PHNECs) treated with TGF- $\beta 1$, or TGF- $\beta 1$ with miR-21 inhibitor, or miR-21 mimics alone were observed for morphology changes under a phase-contrast mi-
\end{abstract}

Edited by: A. Haczku, Sacramento, CA, USA. croscope. The expression levels of epithelial/mesenchymal marker proteins were determined as aforementioned. PTEN and phosphorylated Akt were detected by Western blotting. Results: (1) Tissue experiments: Compared with the CRSsNP and control groups, the expression of E-cadherin was downregulated in the CRSwNP group, whereas the expression of TGF- $\beta 1$, $\alpha-S M A$, fibronectin, and vimentin was upregulated. The expression levels of miR-21 and TGF- $\beta 1$ mRNAs in CRSwNP were significantly higher than those in CRSsNP and controls. (2) Cellular experiments: TGF- $\beta 1$ induced EMT-like transformation in PHNECs, featured by changes in cell morphology and upregulation of mesenchymal proteins and miR-21. The miR-21 inhibitor, as well as the Akt-specific inhibitor, suppressed TGF- $\beta 1$-induced EMT. Mechanically, downregulation of miR-21 resulted in increased PTEN and decreased Akt phosphorylation. Furthermore, overexpression of miR-21 had the opposite effects. Conclusions: Our findings suggest that the TGF- $\beta 1$-miR-21-PTEN-Akt axis may contribute to the pathogenesis of CRSwNP. miR-21 might be a reliable target for treating nasal polyp genesis through EMT suppression. Moreover, miR-21 inhibitors could be a novel class of antipolyp drug that modulates PTEN expression and Akt activation. In addition, further investigation regarding the reason underlying miR-21 overexpression in CRSwNP could provide a molecular target for novel treatment strategies for nasal polyposis.

(c) 2019 S. Karger AG, Basel

\section{KARGER}

(c) 2019 S. Karger AG, Basel

E-Mail karger@karger.com

www.karger.com/iaa
Prof. Zi-an Xiao

Department of Otolaryngology, Head and Neck Surgery Second Xiangya Hospital, Central South University

139 Renmin Road, Changsha, Hunan 410011 (PR China)

E-Mail xiaozian@csu.edu.cn 


\section{Introduction}

Chronic rhinosinusitis (CRS) is a multifactorial inflammatory disease involving the nasal cavity and sinus mucosa. CRS is divided into 2 phenotypes based on nasal endoscopy: CRS with nasal polyps (CRSwNP) and CRS without nasal polyps (CRSsNP), which are heterogeneous [1]. A typical response to chronic inflammation is tissue remodeling. Tissue remodeling is a reconstruction process for wound repair and a dynamic process involving a structural reorganization of tissues [2]. Remodeling is not only linked to chronic inflammatory lower airway disorders, like cystic fibrosis and asthma [3], but also takes place in the upper airways during chronic inflammation like allergic rhinitis or CRS. It can cause pathological changes in the lamina propria, airway epithelium, and submucosal regions in CRS, including inflammatory cell infiltrates, basement membrane thickening, subepithelial edema, and fibrosis [4]. Accordingly, CRSwNP is characterized by diffuse sinus mucosal thickening and benign edematous polyp outgrowths with a histological pattern of chronic mononuclear cell and eosinophil infiltration and airway remodeling, including epithelial goblet cell hyperplasia, an increase in $\alpha$-smooth muscle actin ( $\alpha$-SMA) and myofibroblasts, and an increase in basement membrane and submucosal collagen deposition [510]. However, the mechanisms underlying mucosal remodeling and polyp formation in patients with CRSwNP are unclear.

So far, the mechanism of this tissue remodeling is not precisely understood but may involve epithelial-mesenchymal transition (EMT). EMT is a fundamental biological process involving normal embryogenesis, wound healing, and tissue repair, as well as numerous pathologies, including organ fibrosis, malignant transformation, and cancer progression [11]. Recently, the features of EMT have been observed in CRS and confirmed in nasal polyp tissue [12], which induces loss of epithelium and differentiation to myofibroblasts [13, 14]. Transforming growth factor (TGF)- $\beta 1$, a representative cytokine in tissue repair and remodeling, initiates tissue remodeling in the airway epithelium and nasal tissue through activation of EMT signals [15]. TGF- $\beta 1$ plays an important function in nasal polyp formation and growth, promoting remodeling and cell growth, which stimulate fibrosis (by attracting stromal cells), angiogenesis, and accumulation of extracellular matrix [16]. However, reports about TGF- $\beta 1$ expression in CRSwNP are contradictory, with some investigators reporting increased TGF- $\beta 1$ expression in patients with CRSwNP compared to patients with CRSsNP

TGF- $\beta 1$ Induces EMT of Chronic

Sinusitis with Nasal Polyps via miR-21 and controls $[8,16-21]$, whereas others report low levels in comparison to CRSsNP and normal controls [22-24].

MicroRNAs (miRs) have been shown to play a key role in the regulation of cellular activity. miRs are a class of evolutionarily conserved, endogenous, noncoding, small RNAs, measuring approximately $\sim 22$ nucleotides in length. They are estimated to regulate over $60 \%$ of the protein-coding genes, which bind to the $3^{\prime}$ UTR of target genes and thereby repress translation of target genes and/ or induce degradation of target gene mRNA [25-28].

miR-21 is a polycistronic miR whose gene is located in chromosome 17q23.2, where it overlaps with the proteincoding gene VMP1, also known as TMEM49 [29]. miR21 has been found to be deregulated in almost all types of cancers and is therefore classified as an important oncogenic miR [30]. Recently, miR-21 has been ascribed a crucial role in the regulation of cellular activity during physiological and pathological processes [31]. miR-21 is widely expressed and has been found to be increased in organs and tissues which have suffered fibrogenesis or remodeling, including the heart [32], kidney [33], lung [34], asthmatic airways $[35,36]$, liver $[37,38]$, skin [39-41], and tumor tissue [42, 43]. Studies revealed that enhanced miR-21 expression is involved in the progression of lung fibrosis, and TGF- $\beta 1$ plays an important role in mediating increased miR-21 expression [34, 44]. However, there are no studies investigating the expression changes in miR-21 and the relationship between miR-21 and TGF- $\beta 1$ in EMT of CRSwNP in particular. Although TGF- $\beta / \mathrm{Smad}$ signaling is regarded as the main pathway in EMT, TGF- $\beta$ also activates a Smad-independent signaling pathway, with the direct involvement of TGF- $\beta$-activated kinase $[42,43,45,46]$. Since past researches confirm that PTEN is an miR-21-directed target gene, we hypothesized that miR-21 mediated TGF- $\beta 1$-induced EMT through the PTEN/Akt pathway in PHNECs. Furthermore, we showed for the first time that the important role miR-21 plays in TGF- $\beta 1$-induced EMT in CRSwNP. Besides, the findings suggest that miR-21 might be a reliable target for treating CRSwNP through EMT suppression.

\section{Materials and Methods}

\section{Subjects}

Sinonasal mucosa specimens from 12 patients with CRSsNP, 13 patients with CRSwNP, and 11 control patients were obtained from the Department of Otorhinolaryngology of the Second Xiangya Hospital, Central South University. All study participants were enrolled after providing written informed consent. Inferior turbinates from patients with anatomical variations but without sinus disease undergoing septoplasty or rhinoseptoplasty were col- 
Table 1. Patient characteristics

\begin{tabular}{llll}
\hline & Control & CRSwNP & CRSsNP \\
\hline Patients, $n$ & 11 & 13 & 12 \\
Median age (range), years & $34(12-74)$ & $42(16-61)$ & $41(27-58)$ \\
Females/males, $n$ & $2 / 9$ & $3 / 10$ & $3 / 9$ \\
Skin prick test positive ${ }^{a}, n$ & 0 & 0 & 0 \\
History of asthma, $n$ & 0 & 0 & 0 \\
Aspirin intolerance, $n$ & 0 & 0 & 0 \\
Median duration of CRS (range), years & 0 & $13(1-30)$ & $6(0.5-15)$ \\
Previous sinus surgeries, yes/no & $0 / 11$ & $4 / 9$ & $3 / 9$ \\
Current or recent ex-smokers, yes/no & $4 / 7$ & $4 / 9$ & $4 / 8$ \\
Alcohol abuse, yes/no & $3 / 8$ & $1 / 12$ & $2 / 10$ \\
\hline
\end{tabular}

a Subjects underwent allergy skin prick testing with a panel of 23 prick and 15 intradermal allergens to assess allergic sensitivity. The results are indicated as "positive" if the subject had 1 or more positive skin tests.

lected as controls. For CRSsNP, mucosa samples originated from middle turbinates. For CRSwNP, polyp tissue samples in the middle meatus area were used. The diagnosis of sinus disease was carried out according to a European Position Paper on Rhinosinusitis and Nasal Polyps (EPOS) [1], which is based on history, clinical examination, nasal endoscopy, and sinus CT scans. General exclusion criteria were based on the EPOS definition for research (cystic fibrosis, gross immunodeficiency, congenital mucociliary problems, noninvasive fungal balls and invasive fungal disease, systemic vasculitis, and granulomatous diseases). None of the subjects received antihistamines, antileukotrienes, oral or intranasal decongestants, or intranasal anticholinergics during the 2 weeks prior to surgery. All patients stopped oral and topical application of corticosteroids and antibiotics at least 4 weeks before surgery. Patients with allergies or asthma were excluded from the study, and all patients did not take any other relevant medication. Females who were pregnant or breastfeeding were also excluded from the study. Patient characteristics are detailed in Table 1.

The fresh nasal tissue samples collected during surgery were divided into 2 parts. Half of them were immediately snap frozen in liquid nitrogen and stored at $-80^{\circ} \mathrm{C}$ before quantitative real-time polymerase chain reaction (qRT-PCR) and protein extraction for Western blotting. Others were fixed with $4 \%$ paraformaldehyde for immunofluorescence.

\section{Cell Culture}

Primary human nasal epithelial cells (PHNECs) were purchased from BeNa Culture Collection (Beijing, China). PHNECs were cultured in RPMI-1640 medium supplemented with $10 \% \mathrm{fe}$ tal bovine serum (FBS) in an incubator at $37^{\circ} \mathrm{C}$ and $5 \% \mathrm{CO}_{2}$. Cultured cells had monolayer growth, and the rate of cells passaging the attachment reached $80-90 \%$. The purity of PHNECs was confirmed through positive staining for cytokeratin $6 \mathrm{~A}$ by immunocytochemistry.

\section{Immunofluorescence}

Cells were fixed with $4 \%$ paraformaldehyde, permeabilized with $0.5 \%$ Triton X-100 in $1 \%$ bovine serum albumin (BSA) for $30 \mathrm{~min}$, and blocked with 5\% BSA for $1 \mathrm{~h}$ at room temperature. Tissues and cells were stained with primary antibodies (E-cadherin, a-SMA, fibronectin, and vimentin), incubated with Alexa Fluor 594-conjugated donkey anti-rabbit lgG secondary antibodies (Proteintech; USA) and finally counterstained with 4'-6-diamidino-2-phenylindole (DAPI; Wellbio). Images of immunostained cells and tissues were captured using a confocal microscope (Motic).

\section{Transient Transfection Analysis}

Cells were seeded in $25-\mathrm{cm}^{2}$ culture flasks and grown in complete medium to a density of $30-50 \%$. Lipofectamine 2000 (5 $\mu \mathrm{L}$; Invitrogen Company, USA) was diluted with $100 \mu \mathrm{L}$ serum-free medium and then kept at room temperature for $5 \mathrm{~min}$. DNA $(1 \mu \mathrm{g})$ was diluted with $100 \mu \mathrm{L}$ serum-free culture medium. Both dilutions were gently mixed and stored at room temperature for 20 min for complex formation, and serum-free culture medium was used to wash cells. Serum-free culture medium was added to the complex, and then the complex was transferred to culture flasks for transfection at $37^{\circ} \mathrm{C}$ in $5 \% \mathrm{CO}_{2}$. Complete medium was added $6 \mathrm{~h}$ later, and cells were cultivated continuously.

\section{qRT-PCR Assay}

Total RNA was extracted from tissue specimens and cells by TRIzol (Beijing ComWin Biotech Co., Ltd., China) according to the manufacturer's protocol and dissolved in ultrapure water which was processed by diethylpyrocarbonate (DEPC; Sigma, USA). The quality of total RNA was identified by measuring absorbance at 260 and $280 \mathrm{~nm}$ using a spectrophotometer. According to miR cDNA synthesis kit instructions (Beijing ComWin Biotech Co., Ltd., China), RNA was extracted from tissues, and cells were reversely transcribed. The reaction conditions were: $37^{\circ} \mathrm{C}$ for 15 min, ice bath for $2 \mathrm{~min}, 42^{\circ} \mathrm{C}$ for $50 \mathrm{~min}, 85^{\circ} \mathrm{C}$ for $5 \mathrm{~min}$, and then cDNA was directly used for $\mathrm{qRT}$-PCR or temporarily placed at $-20^{\circ} \mathrm{C}$. SYBR Green I (Newprobe, China) was used in qRT-PCR according to the manufacturer's protocol. PCR was performed using the appropriate primers (primer sequences are shown in Table 2). The reaction conditions consisted of the following cycles: predenaturation at $95^{\circ} \mathrm{C}$ for $10 \mathrm{~min}$, denaturation at $95^{\circ} \mathrm{C}$ for $15 \mathrm{~s}$, annealing and extension at $60^{\circ} \mathrm{C}$ for $1 \mathrm{~min}$, which were repeated 40 times. The test was performed using qRT-PCR (PIKO REAL 96; Thermo, USA). The internal reference of miR-21 was small nuclear RNA U6, and the mRNA expression of GAPDH, a housekeep- 
ing gene, was considered to be the endogenous control of the other genes for normalization. The relative quantification method [47] was used for calculation and $2^{-\Delta \Delta C_{t}}$ was used to represent the relative multiple expression of target genes. All experiments were repeated 3 times.

\section{Western Blotting}

Tissues and cells were first washed with PBS, then homogenized using $300 \mu \mathrm{L}$ RIPA buffer (Applygen Technologies, Inc., China). Homogenates were clarified by centrifugation at 12,000 rpm for $15 \mathrm{~min}$ at $4{ }^{\circ} \mathrm{C}$, and the protein concentration was measured using the BCA protein assay kit (WellBiology). Equal amounts of proteins from each sample were separated by SDS polyacrylamide gel electrophoresis (Bio-Rad, USA). Separated proteins were transferred to PVDF membranes (Millipore). Blots were blocked in Tris-buffered saline (TBS) containing 5\% skim milk for $1.5 \mathrm{~h}$ at room temperature and incubated overnight at $4{ }^{\circ} \mathrm{C}$ with primary antibodies against TGF- $\beta 1$, E-cadherin, vimentin, $\alpha$-SMA, fibronectin, and $\beta$-actin (Proteintech, USA) diluted in TBST (Sigma, USA). After incubation with the corresponding peroxidase-conjugated secondary antibody for $90 \mathrm{~min}$ at room temperature, the specific protein was detected using an enhanced chemiluminescence system (Thermo Pierce, USA).

\section{Statistical Analysis}

At least 3 independent experiments provided the results in this study. The data were analyzed by IBM SPSS 22.0 and GraphPad Prism software 7.0. Results are expressed as means \pm SEM. Differences between the values were determined by Student-NewmanKeuls q test or analysis of variance (ANOVA). A 95\% confidence level established significance. All statistical tests were 2 -sided, and significance was considered when the $p$ value was less than 0.05 .

\section{Results}

Reduced Expression of Epithelial Markers and Increased Expression of TGF- $\beta 1$ and Mesenchymal Markers in CRSwNP

To investigate whether EMT occurs in CRSwNP in vivo, Western blotting and immunofluorescence were performed. We examined protein expression of TGF- $\beta 1$ and the EMT markers including E-cadherin, vimentin, a-SMA, and fibronectin in CRSwNP, CRSsNP, and controls. E-cadherin expression was reduced in CRSwNP compared to CRSsNP $(0.16 \pm 0.031$ vs. $0.31 \pm 0.006, p=$ $0.000)$ and controls $(0.16 \pm 0.031$ vs. $0.68 \pm 0.059, p=$ $0.000)$. TGF- $\beta 1$ protein expression was increased in CRSwNP compared to CRSsNP ( $0.62 \pm 0.030$ vs. $0.35 \pm$ $0.043, p=0.000)$ and controls $(0.62 \pm 0.030$ vs. $0.19 \pm$ $0.033, p=0.000)$. Expression of the mesenchymal marker vimentin was higher in CRSwNP than CRSsNP (0.40 \pm 0.038 vs. $0.22 \pm 0.112, p=0.001)$ and controls $(0.40 \pm$ 0.038 vs. $0.15 \pm 0.013, p=0.000)$. $\alpha$-SMA expression was increased in CRSwNP compared to CRSsNP $(0.43 \pm 0.030$
Table 2. Primer sequence for quantitative real-time polymerase chain reaction assay

\begin{tabular}{ll}
\hline Target gene & Primer sequence \\
\hline miR-21-5p & TAGCTTATCAGACTGATGTTGA \\
\hline U6 & F: $5^{\prime}$-CTCGCTTCGGCAGCACA-3' \\
& R: $5^{\prime}$-AACGCTTCACGAATTTGCGT-3' \\
\hline GAPDH & F: $5^{\prime}$-ACAGCCTCAAGATCATCAGC-3' \\
& R: $5^{\prime}$-GGTCATGAGTCCTTCCACGAT-3' \\
\hline TGF- $\beta 1$ & F: $5^{\prime}$-GGCCAGATCCTGTCCAAGC-3' \\
& R: $5^{\prime}$-GTGGGTTTCCACCATTAGCAC-3' \\
\hline
\end{tabular}

F, forward; R, reverse.

vs. $0.32 \pm 0.037, p=0.000)$ and controls $(0.43 \pm 0.030$ vs. $0.22 \pm 0.051, p=0.000$ ), and fibronectin expression in CRSwNP was also strongly increased compared to CRSs$\mathrm{NP}(0.33 \pm 0.041$ vs. $0.14 \pm 0.028, p=0.000)$ and controls $(0.33 \pm 0.041$ vs. $0.06 \pm 0.012, p=0.000)$ (Fig. 1a, b). Staining for E-cadherin expression was reduced in epithelial cells from CRSwNP compared to the other two groups. However, the mesenchymal markers vimentin, a-SMA, and fibronectin were strongly positive in submucosal tissue of CRSwNP. However, in the other two groups, both epithelium and submucosa were negative for these mesenchymal markers (Fig. 1c).

\section{Increased Expression of $m i R-21$ and TGF- $\beta 1 \mathrm{mRNA}$ in $C R S w N P$}

As presented in Figure 2, miR-21 expression in CRSwNP was significantly increased compared with CRSsNP (113.10 \pm 36.3 vs. $21.99 \pm 14.6, p=0.016)$ and controls (113.10 \pm 36.3 vs. $55.74 \pm 16.8, p=0.045)$. In agreement with the data on miR-21, qRT-PCR showed that TGF- $\beta 1$ mRNA expression was significantly higher in CRSwNP than CRSsNP $(0.74 \pm 0.11$ vs. $0.36 \pm 0.08$, $p=0.002)$ and controls $(0.74 \pm 0.11$ vs. $0.44 \pm 0.03$, $p=0.015)$.

\section{TGF- $\beta 1$ Upregulated miR-21 and Induced EMT in PHNECS}

A previous study confirmed that TGF- $\beta 1$ induces EMT in primary airway epithelial cells [15]. Therefore, we tested the capacity of TGF- $\beta 1$ to induce EMT in PHNECs. Cells were stimulated with TGF- $\beta 1(5 \mathrm{ng} / \mathrm{mL})$ for 5 days. Phase-contrast microscopy revealed that treatment with TGF- $\beta 1$ changed PHNECs from normal epithelial morphology with a cobblestone-like appear-
TGF- $\beta 1$ Induces EMT of Chronic

Sinusitis with Nasal Polyps via miR-21
Int Arch Allergy Immunol 2019;179:304-319 DOI: $10.1159 / 000497829$ 
Fig. 1. Reduced expression of epithelial markers and increased expression of mesenchymal markers and TGF- $\beta 1$ in CRSwNP. Protein expression of EMT markers and TGF- $\beta 1$ detected by Western blotting (a). Western blotting demonstrated downregulation of E-cadherin expression but upregulation of TGF- $\beta 1, \alpha$-SMA, fibronectin, and vimentin expression in CRSwNP compared to CRSsNP and controls $\left(\mathbf{a}^{\prime}\right)$. The location of EMT markers E-cadherin, vimentin, $\alpha$-SMA, and fibronectin was determined by immunofluorescence (b). Representative fluorescein immunocytochemical staining is shown with EMT markers (red) and nuclear DAPI (blue). ${ }^{* *} p<0.01,{ }^{* * *} p<0.001$.

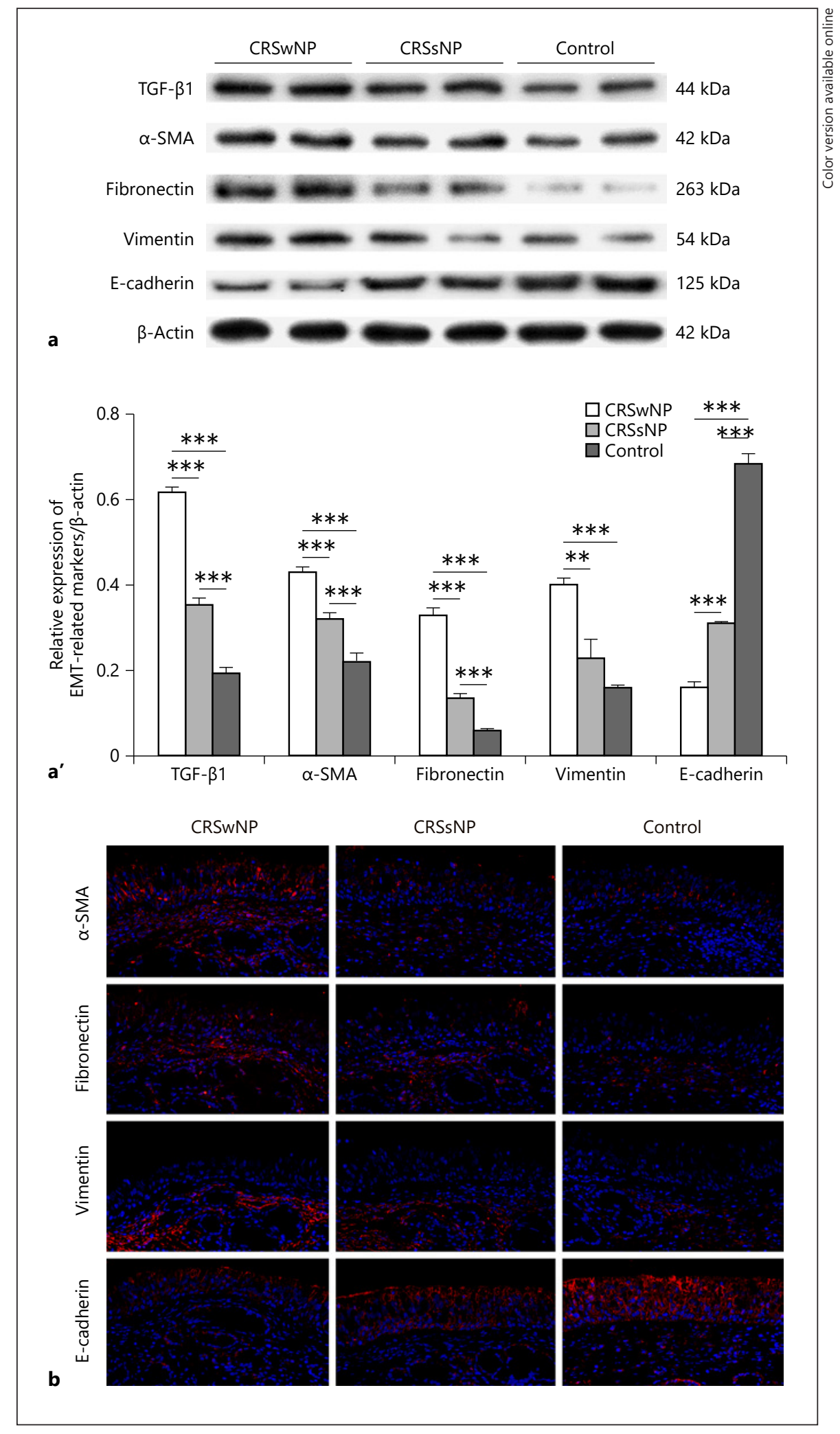




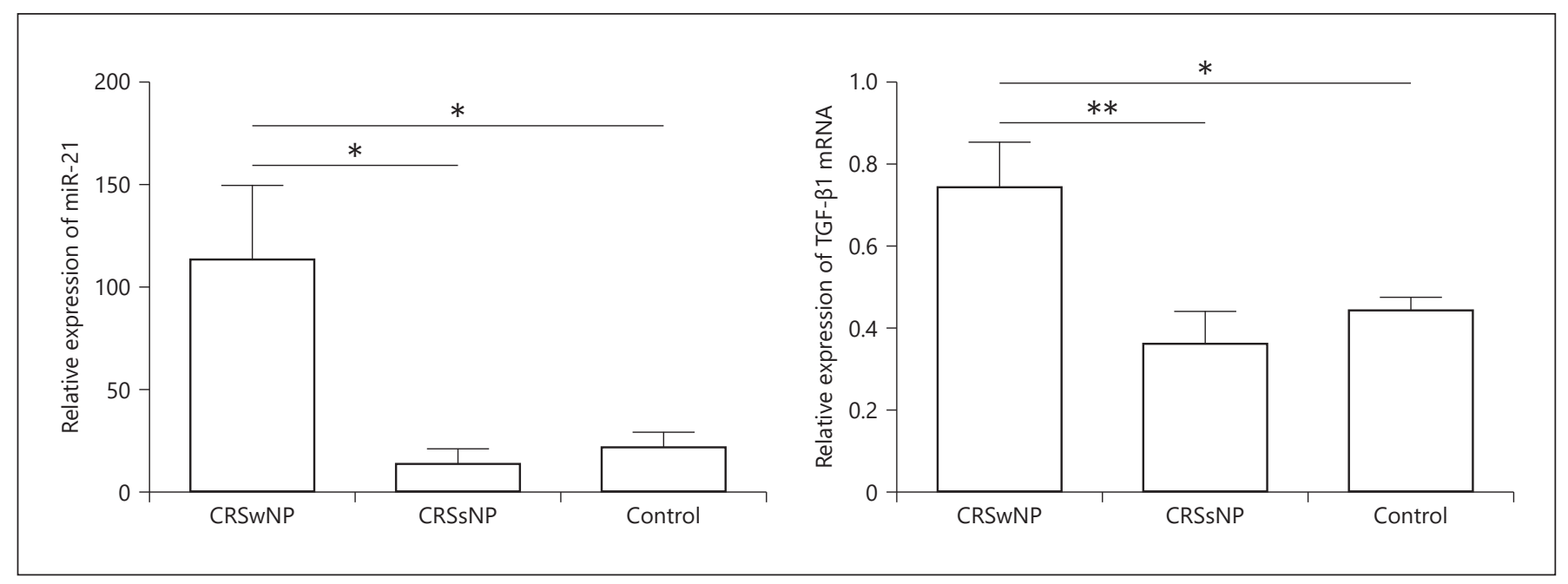

Fig. 2. Increased miR- 21 and TGF- $\beta 1$ mRNA expression in CRSwNP. qRT-PCR showed that miR-21 and TGF- $\beta 1$ mRNA expression in CRSwNP was significantly increased compared with CRSsNP and controls. Each bar represents the mean \pm SEM. Results were from at least 3 independent experiments. ${ }^{*} p<0.05,{ }^{* *} p<0.01$.

ance (Fig. 3a) into a migratory mesenchymal morphology with an abnormally elongated appearance (Fig. 3b), which means TGF- $\beta 1$ treatment could lead PHNECs to undergo EMT-like transformation. During the EMT progression, cell-cell adhesion and epithelial cell polarity gradually decreased, and epithelial cells changed into mesenchymal cells. Expression of E-cadherin, vimentin, fibronectin, and $\alpha$-SMA proteins as EMT marker was examined using Western blotting. Consistent with the observed morphological changes, TGF- $\beta 1$ treatment decreased the expression of the epithelial marker E-cadherin but increased the expression of the mesenchymal markers vimentin, fibronectin, and a-SMA using Western blotting and fluorescent immunocytochemical staining (Fig. 3c, d). In previous studies, miR-21 expression was increased in fibrotic disease and rapidly inducible by TGF- $\beta 1[34,48,49]$. We then examined expression changes of miR-21 in PHNECs following TGF- $\beta 1$ treatment. Expression of miR-21 was upregulated after treatment with $5 \mathrm{ng} / \mathrm{mL}$ of TGF- $\beta 1$, suggesting that it may play an important role in TGF- $\beta 1$-induced EMT (Fig. 3e).

miR-21 Mediated TGF- $\beta 1$-Induced EMT in PHNECs

In order to confirm the role of miR-21 in EMT, we examined whether inhibition of miR-21 could attenuate EMT induced by TGF- $\beta 1$ in PHNECs. After downregulation of miR-21 expression in PHNECs following transfection with the miR-21 inhibitor, EMT was inhibited significantly. First of all, morphological changes induced by
TGF- $\beta 1$ were ameliorated (Fig. 4a, b). Second, consistent with the observed morphological changes, we observed the recovery of E-cadherin expression and loss of vimentin, fibronectin, and a-SMA expression by Western blotting and immunofluorescence staining after downregulation of miR-21 expression (Fig. 4c, c', d). Furthermore, we found that overexpression of miR-21 alone also resulted in EMT-like transformation in PHNECs (Fig. 4e,f). Transfection of miR-21 mimics into PHNECs leads to reduced E-cadherin and increased vimentin, fibronectin, and $\alpha$-SMA expression (Fig. 4g, $g^{\prime}, \mathrm{h}$ ).

\section{miR-21 Mediated TGF- $\beta 1$-Induced EMT through the} PTEN/Akt Pathway in PHNECs

The results showed that TGF- $\beta 1$ treatment resulted in decreased PTEN and increased Akt phosphorylation. However, downregulation of miR-21 reversed this effect, indicating that miR- 21 regulates the TGF- $\beta 1$-induced PTEN/Akt pathway in PHNECs (Fig. 5a, a'). Then, overexpression of miR-21 in PHNECs downregulated PTEN and upregulated Akt phosphorylation (Fig. 5b, b'), suggesting that the PTEN/Akt pathway is a miR-21 target in PHNECs. We next verified whether the PTEN/Akt pathway affected miR-21 mediated TGF- $\beta 1$-induced EMT in PHNECs. The results showed the specific inhibitor for Akt activation significantly weakened EMT by increasing E-cadherin and decreasing vimentin, fibronectin, and a-SMA (Fig. 5c, $c^{\prime}, d$ ), suggesting miR-21 mediated TGF- $\beta 1$-induced EMT through the PTEN/Akt pathway in PHNECs. 


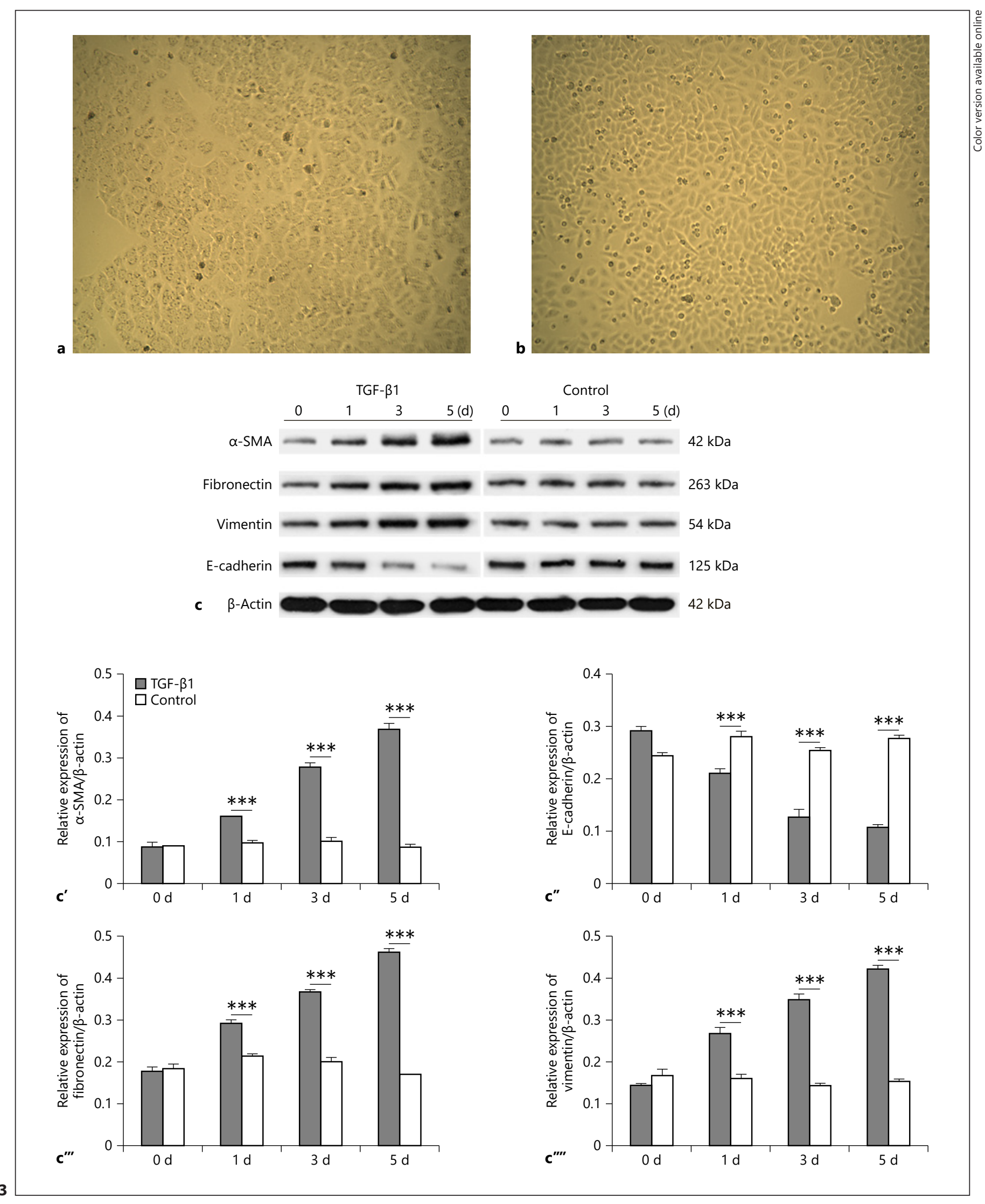

(Figure continued on next page.) 


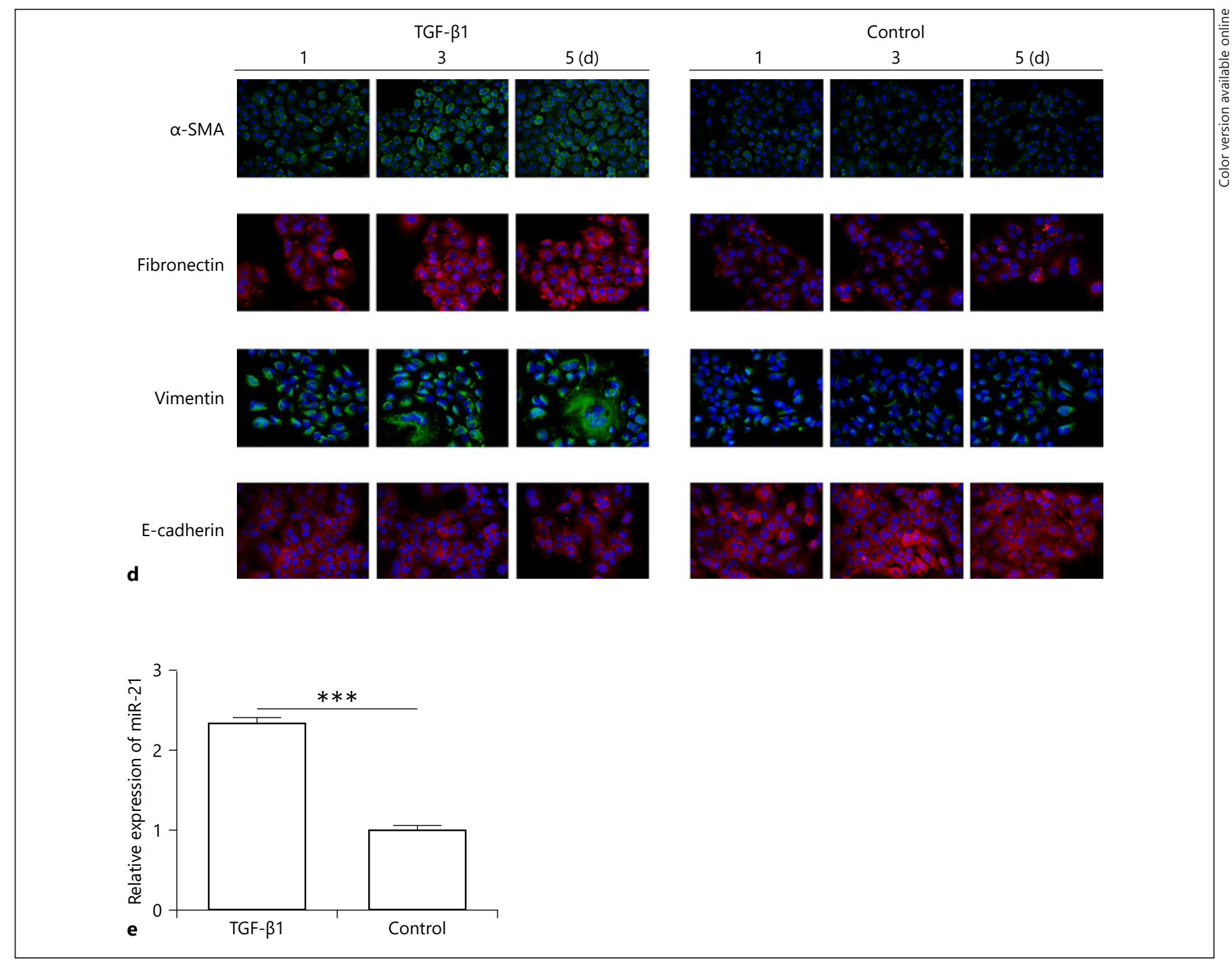

Fig. 3. TGF- $\beta 1$ upregulated miR- 21 and induced EMT in PHNECs. Effect of $5 \mathrm{ng} / \mathrm{mL}$ TGF- $\beta 1$ for 5 days (d) on cell morphology of PHNECs observed under a phase-contrast microscope $(\times 100)$. Phase-contrast microscopy revealed that treatment with TGF- $\beta 1$ changed PHNECs from normal epithelial morphology with a cobblestone-like appearance (a) into a migratory mesenchymal morphology with an abnormally elongated appearance (b). PHNECs were treated with $5 \mathrm{ng} / \mathrm{mL}$ TGF- $\beta 1$ for different times. The protein expression of E-cadherin, vimentin, fibronectin, and a-SMA was examined by Western blotting $\left(\mathbf{c}-\mathbf{c}^{\prime \prime \prime \prime}\right)$ and immunofluorescence staining (d). Representative fluorescein immunocytochemical staining is depicted with a-SMA (green), fibronectin (red), vimentin (green), E-cadherin (red), and nuclear DAPI (blue). After PHNECs were treated with $5 \mathrm{ng} / \mathrm{mL}$ TGF- $\beta 1$ for 5 days, miR-21 expression was measured by qRT-PCR $(\mathbf{e}) .{ }^{* *} p<0.01,{ }^{* * *} p<0.001$.
Fig. 4. miR-21-mediated TGF- $\beta 1$-induced EMT in PHNECs. Following transfection with the miR-21 inhibitor (a), the morphological changes induced by TGF- $\beta 1$ were ameliorated compared with the control group (b) by phase-contrast microscopy $(\times 100)$. Protein expression of E-cadherin, vimentin, fibronectin, and a-SMA was examined by Western blotting (c, $\left.\mathbf{c}^{\prime}\right)$ and immunofluorescence staining (d). After transfection of miR-21 mimics (e), we found that overexpression of miR-21 alone also resulted in EMT-like transformation in PHNECs compared with control (f). The protein expression of E-cadherin, vimentin, fibronectin, and $\alpha$-SMA was examined by Western blotting $\left(\mathbf{g}, \mathbf{g}^{\prime}\right)$ and immunofluorescence staining (h). NC, negative control. ${ }^{* *} p<0.01,{ }^{* * *} p<0.001$.

(For figure see next pages.) 


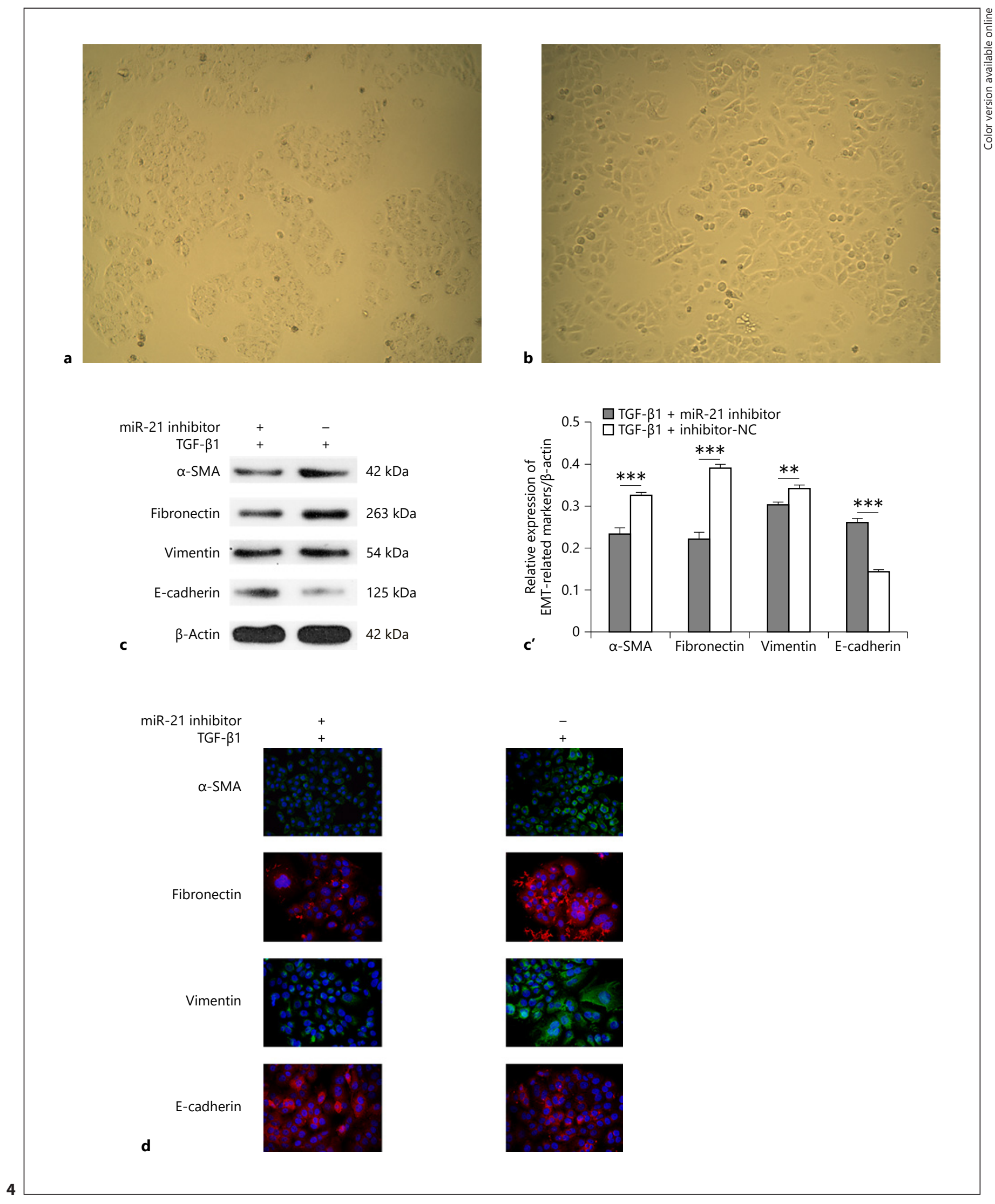




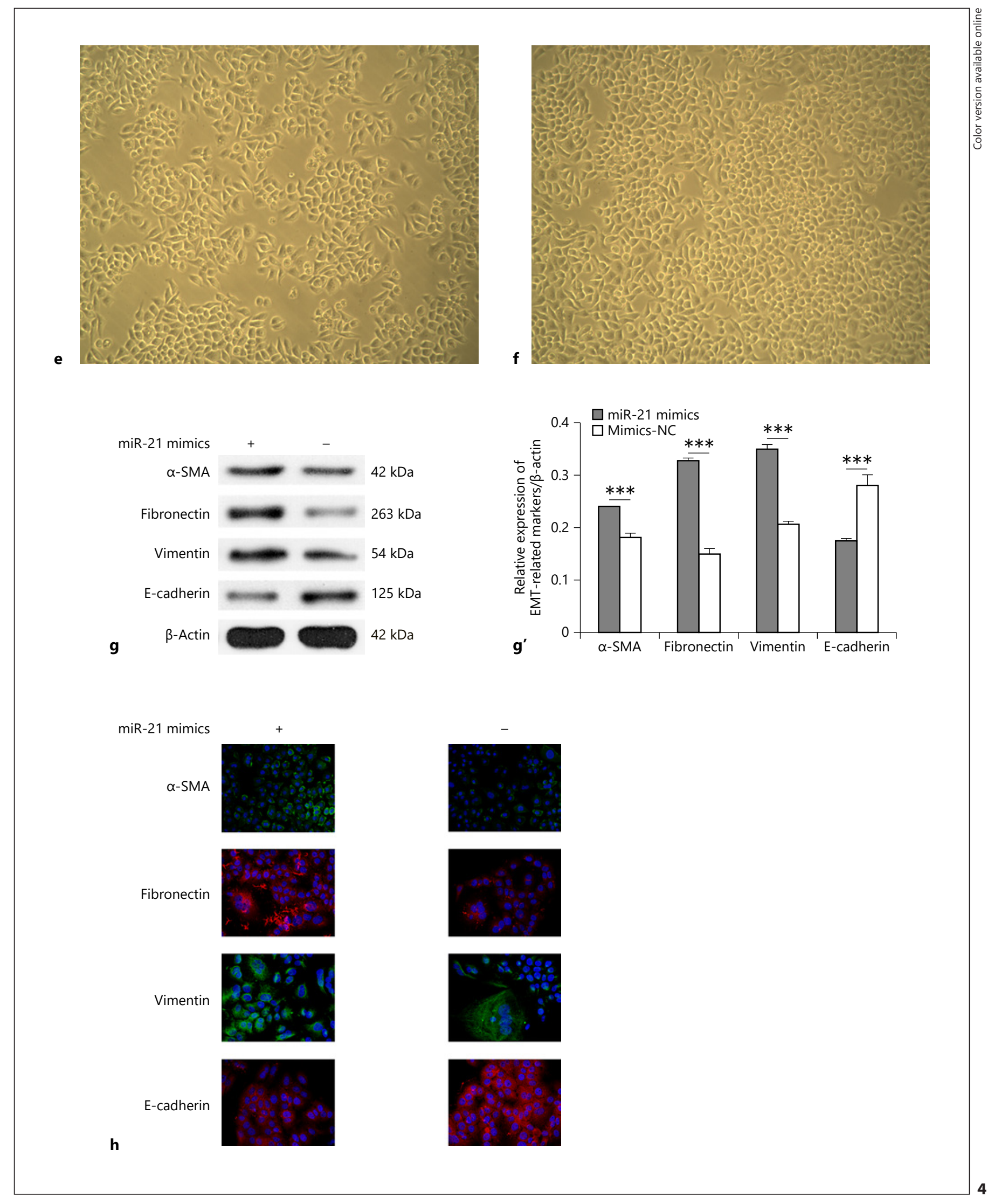



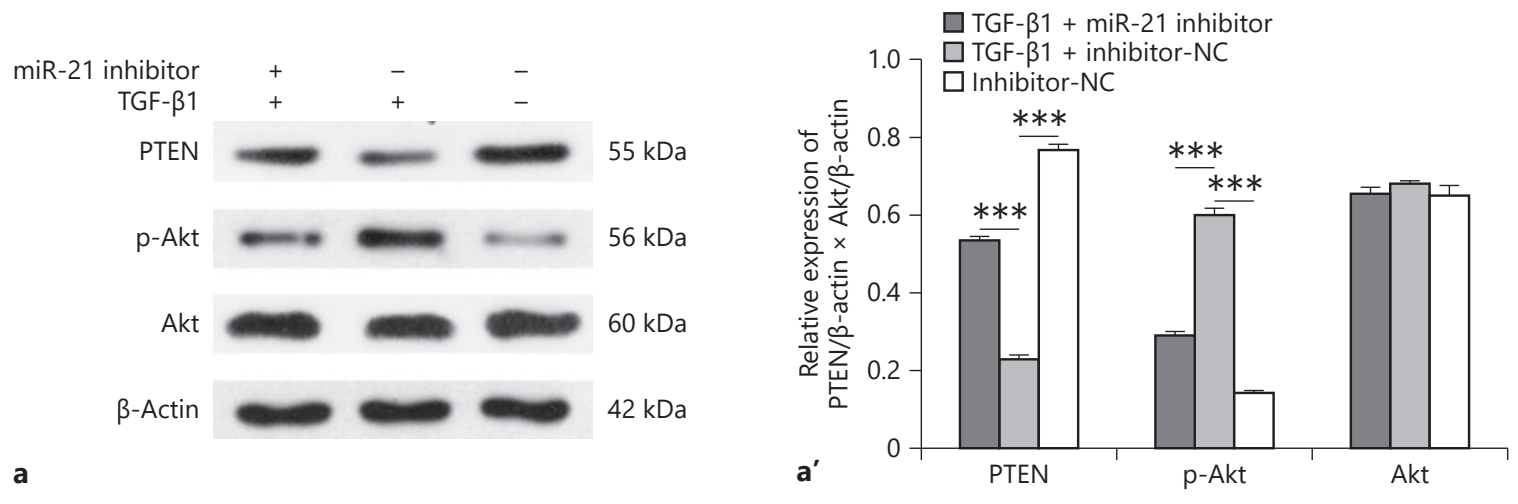

a

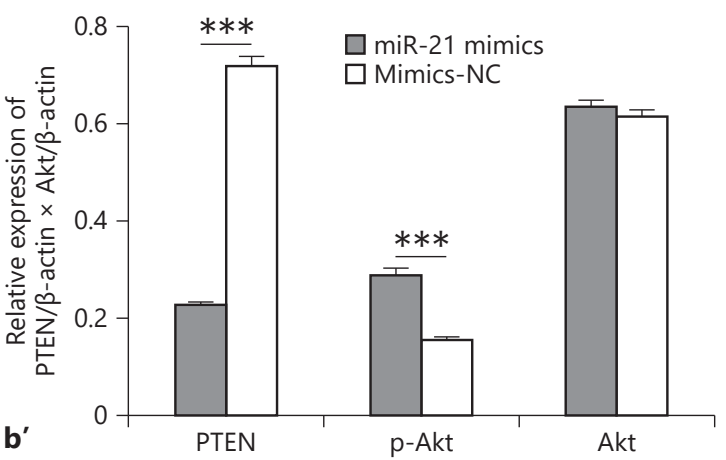

b

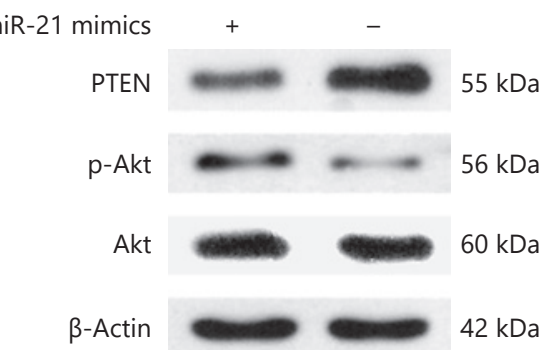

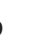
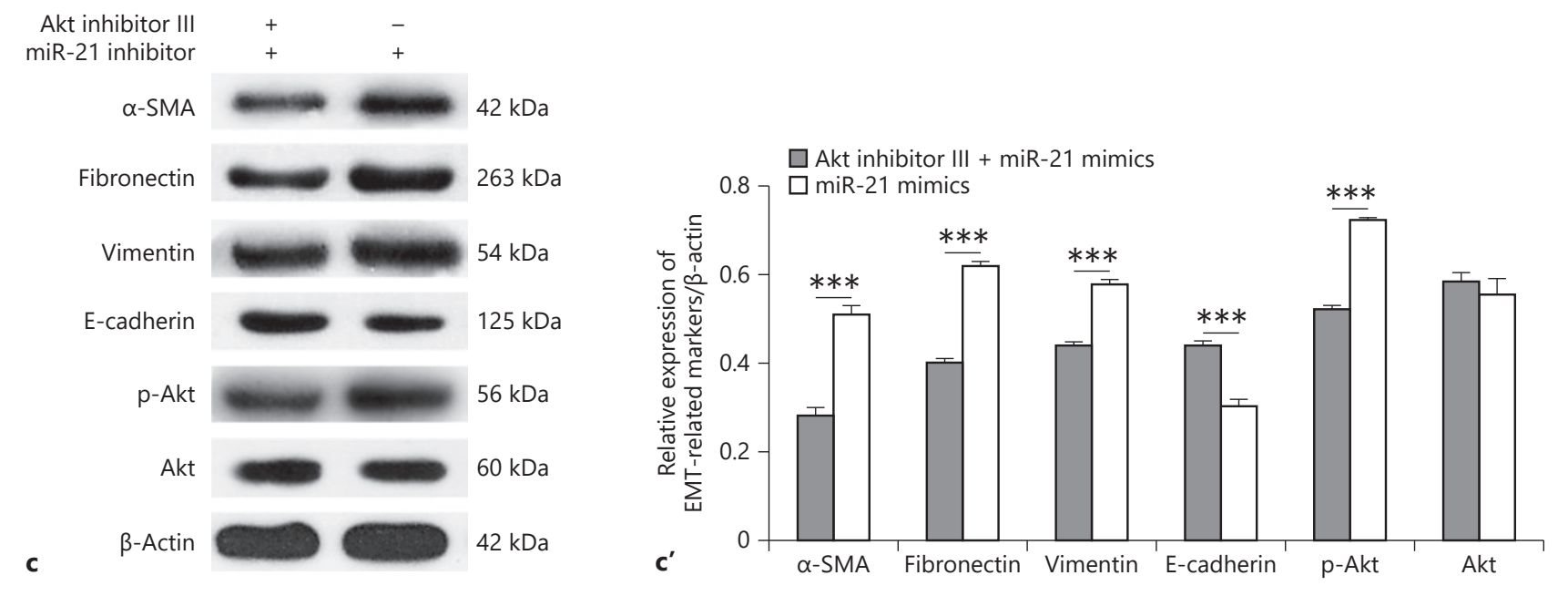

Fig. 5. miR-21 mediated TGF- $\beta 1$-induced EMT through the PTEN/Akt pathway in PHNECs. Cells were treated with $5 \mathrm{ng} / \mathrm{ml}$ TGF- $\beta 1$ after downregulating miR-21. TGF- $\beta 1$ treatment resulted in decreased PTEN and increased Akt phosphorylation. However, downregulation of miR-21 reversed this effect $\left(\mathbf{a}, \mathbf{a}^{\prime}\right)$. Overexpression of miR-21 in PHNECs downregulated PTEN and upregulated Akt phosphorylation $\left(\mathbf{b}, \mathbf{b}^{\prime}\right)$. Cells were treated with $5 \mu \mathrm{M}$ Akt in- hibitor III after upregulating miR-21. The specific inhibitor for Akt activation significantly weakened EMT by increasing E-cadherin and decreasing vimentin, fibronectin, and a-SMA (c, $\mathbf{c}^{\prime}, \mathbf{d}$ ). The protein expression of E-cadherin, vimentin, fibronectin, and $\alpha$-SMA was examined by Western blotting (c, $\left.\mathbf{c}^{\prime}\right)$ and immunofluorescence staining (d). ${ }^{* * *} p<0.001$.

(Figure continued on next page.) 


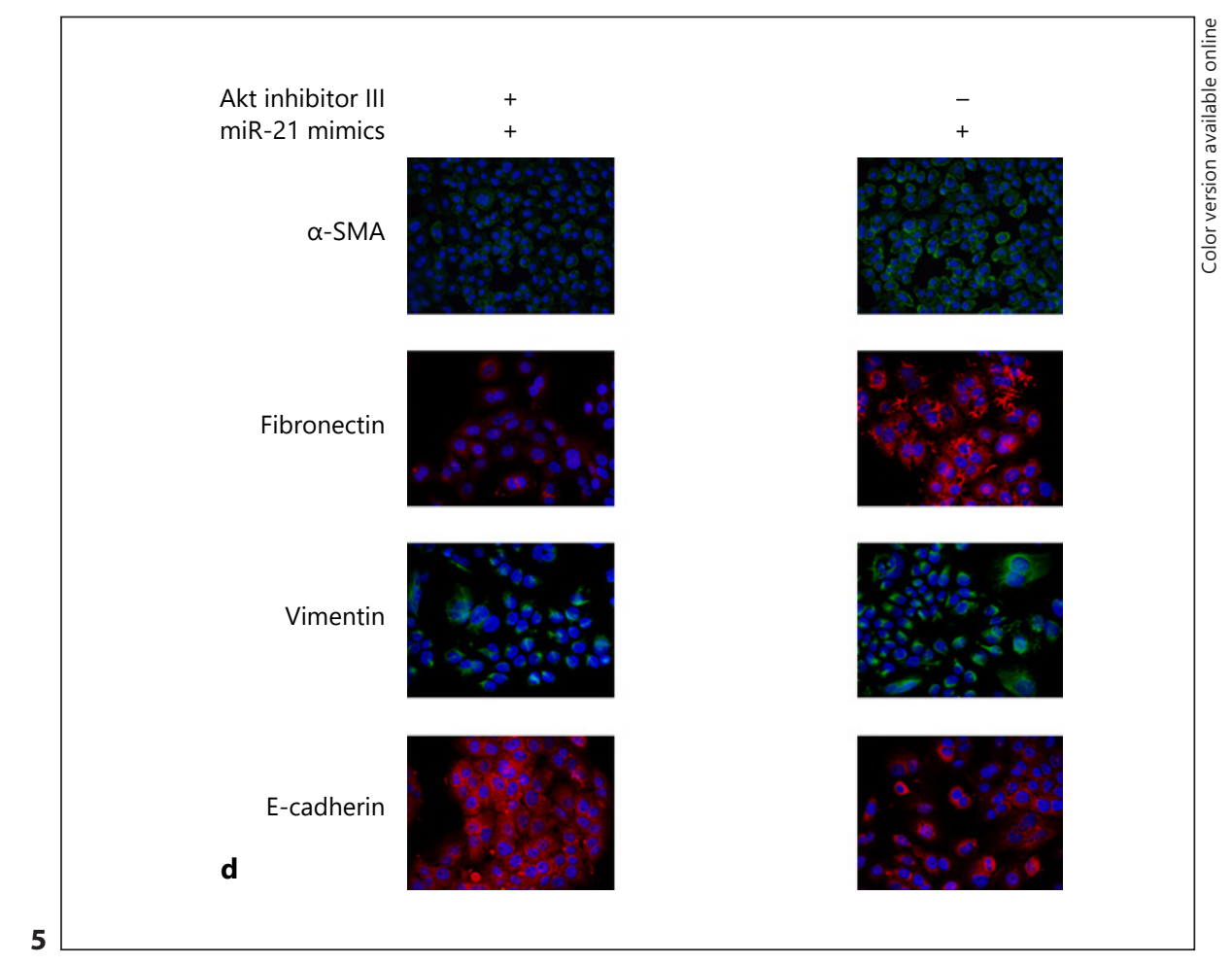

\section{Discussion/Conclusion}

In this study, we showed that miR-21 mediates EMT in PHNECs via the PTEN/Akt pathway in response to TGF- $\beta 1$. To our knowledge, this is the first report regarding the important role miR-21 plays in EMT in CRSwNP. Although dysregulation of miRs is known to be involved in a variety of pathophysiological processes, the role of miRs in CRSwNP is unclear. miR-21 has previously been shown to be induced by an increased level of TGF- $\beta 1$ during smooth muscle cell development [49]. Soon afterwards, studies revealed that the enhanced expression of miR-21 is involved in the progression of lung fibrosis, and TGF- $\beta 1$ plays an important role in mediating the increased miR-21 expression $[34,44]$. Because TGF- $\beta 1$, a well-known stimulator of EMT, induces the transition of epithelial cells into myofibroblasts, contributing to tissue remodeling and the pathogenesis of CRSwNP $[15,17]$, the induction of miR-21 by TGF- $\beta 1$ suggests that miR- 21 may have a potential role in the pathogenesis of CRSwNP. The related literature [15, $17,34,44]$ was consistent with our findings.

CRS is defined as a chronic inflammatory disease involving the nasal cavity and sinus mucosa, which accompanies symptoms such as nasal obstruction, nasal airway inflammation, facial pain, or olfactory dysfunction and na- sal discharge lasting for more than 12 weeks. Typically, it has been divided into CRSwNP and CRSsNP based on the presence or absence of polyps on endoscopic examinations [1]. CRS results in a substantial burden with a prevalence of about $12.5 \%$ in the population [50] and is estimated to affect over 10 million patients in the US, leading to total annual costs of USD 22 billion [51]. Besides inflammation, these chronic upper airway disorders are characterized by remodeling of structural components, especially of the epithelium [13]. Remodeling is a normal and essential reconstructive process when it occurs in response to a minor inflammatory condition. On the contrary, dysregulated remodeling, such as that caused by severe or chronic longlasting inflammation, can cause pathological reconstruction and pathological tissue formation during the progression of healing and repairing [52]. Inflammation results in a varied degree of tissue injury depending on the disease and its severity, which means that remodeling takes place in all inflammatory diseases including CRSwNP. In the past, remodeling in upper airway chronic inflammatory diseases, such as CRS, received little attention. This could be partly due to the fact that remodeling of the upper airways does not result in the same fatal airflow limitations that occur in patients with asthma and chronic obstructive pulmonary disease. Recently, however, there has been in- 
creased concern about the role of remodeling in upper airway diseases, including CRS, for 2 main reasons. On the one hand, upper airway remodeling can lead to irreversible structural changes, which could explain the recalcitrance of disease $[53,54]$. On the other hand, remodeling begins early in the development of disease and therefore plays an important role in disease progression [12].

Until now, the mechanism of this tissue remodeling is not precisely understood but may involve EMT. Therefore, EMT is also receiving great attention as a convergence point between inflammation and pathological remodeling in many progressive fibrotic diseases. EMT is known as the feature of epithelial cells losing their epithelial character (such as cell-to-cell adhesion and apical-basal polarity) and acquiring mesenchymal properties and eventually contributing to the local fibroblast pool $[55,56]$, which means it is also a process by which fully differentiated epithelial cells undergo a phenotypic conversion and develop a mesenchymal cell phenotype. Accumulating evidence has confirmed that ongoing EMT leads to loss of epithelial barrier function, which would also contribute to disease progression, especially in CRSwNP [57]. Upon injury, epithelial cells undergoing EMT usually downregulate junctional proteins (such as E-cadherin) whilst modulating their cytoskeletal organization and acquiring mesenchymal features such as a-SMA, vimentin, and fibronectin filaments, which results in morphological changes $[11,58]$. In agreement with previous reports $[11,58]$, our study shows that E-cadherin expression was downregulated, but $\alpha$-SMA, fibronectin, and vimentin expression was upregulated in CRSwNP tissue compared to CRSsNP and controls. CRSsNP is traditionally characterized by fibrosis, basement membrane thickening, and goblet cell hyperplasia. TGF- $\beta$, a key mediator in promoting fibrosis and airway remodeling, was found to be elevated in CRSsNP compared to healthy controls [23], which is in agreement with our findings.

A previous study confirmed that TGF- $\beta 1$ is a multifunctional peptide that regulates proliferation, differentiation, adhesion, migration, and other cellular functions and is involved in the pathogenesis of a variety of airway diseases related to remodeling, including CRS [57]. TGF- $\beta 1$ initiates EMT signaling by binding to type I and type II receptor serine/threonine kinase on the cell surface [59], regulating gene expression by receptor-mediated activation of Smad (R-Smad) transcription factors [60]. Despite contradictory reports about TGF- $\beta 1$ expression in CRSwNP, its unclear pathophysiology, and underlying mechanisms of nasal polyp formation, TGF- $\beta 1$ is considered to be a well-known master player in fibrosis and EMT, inducing the transition of epithelial cells into myofibroblasts and contributing to tissue remodeling and the pathogenesis of CRSwNP [15, $17,61,62]$. Our tissue experiments showed that mRNA and protein expression of TGF- $\beta 1$ was strongly increased in CRSwNP. In cellular experiments, TGF- $\beta 1$ changed PHNECs from normal epithelial morphology with a cobblestone-like appearance into a migratory mesenchymal morphology with an abnormally elongated appearance, and the protein expression of EMT markers observed was consistent with that in CRSwNP tissues.

miRs are a class s of small noncoding RNAs whose mature products are $\sim 22$ nucleotides long. They negatively regulate gene expression by inducing translational inhibition or transcript degradation [63]. miR-21 has recently been recognized as a biomarker in various types of diseases, and it has also been confirmed to mediate TGF- $\beta$ signaling and EMT. Zhong et al. [33] provided the first in vitro evidence that miR-21 played a vital role in renal fibrosis in response to TGF- $\beta$. Ong et al. [34] demonstrated that TGF- $\beta 1$ induced miR-21 expression in tissue repair and remodeling of lung diseases such as chronic obstructive pulmonary disease. Liu et al. [37] demonstrated that miR-21 was required for TGF- $\beta$-induced fibrogenic EMT in hepatocytes. miR-21 was overexpressed in human keloid fibroblasts induced by TGF- $\beta 1$ [41]. Besides, miR-21 could promote TGF- $\beta 1$-induced EMT in gastric cancer cells [42] and promotes breast cancer progression and chemoresistance through TGF- $\beta 1$ stimulation [43]. Since an in vivo model system of nasal polyps has not been established, the results of our tissue experiments showed the significantly increased expression of miR-21 in CRSwNP. Cellular experiments confirmed miR-21 upregulation by TGF- $\beta 1$ treatment in PHNECs, and overexpression of miR-21 alone also resulted in EMT-like transformation in PHNECs. Following downregulation of miR-21 expression in PHNECs, EMT was significantly inhibited.

PTEN and Akt pathways were associated with miR21 -induced EMT, and past research confirmed that PTEN is an miR-21-directed target gene [64-68]. Meng et al. showed that if miR-21 was inhibited, expression of its target gene PTEN would upregulate [69]. Previous studies indicated that PTEN expression is regulated by TGF- $\beta 1$ $[43,70]$, which suggested TGF- $\beta 1$ treatment leads to downregulation of PTEN. The PTEN/Akt pathway is also subjected to TGF- $\beta 1$ regulation. Akt activity increases in response to TGF- $\beta 1$ treatment, which seems to be required for a variety of TGF- $\beta$-induced activities $[71,72]$. In addition, PTEN is thought to be an inhibitor of the $\mathrm{PI} 3 \mathrm{~K} / \mathrm{AKT}$ pathway which is central to EMT regulation [73]. To confirm the relationship between miR-21 and PTEN in EMT of CRSwNP, our study used an miR- 
21-targeted molecular technique and identified PTEN, Akt, and p-Akt as target genes of miR-21 through online prediction. We measured PTEN, Akt, and p-Akt during miR-21-mediated TGF- $\beta 1$-induced EMT in PHNECs. In addition, it illustrated that TGF- $\beta 1$ treatment resulted in decreased PTEN and increased Akt phosphorylation, and downregulation of miR-21 abolished this effect. Furthermore, overexpression of miR-21 alone in PHNECs downregulated PTEN and upregulated Akt phosphorylation, and Akt inhibitor III, a specific inhibitor for Akt activation, significantly abolished miR-21-regulated EMT.

Taken together, our findings suggest that miR-21 might be a reliable target for treating nasal polyp genesis through EMT suppression. Moreover, miR-21 inhibitors could be a novel class of antipolyp drugs that modulate PTEN expression and Akt activation. In addition, further investigation regarding the reason underlying miR-21 overexpression in CRSwNP could provide a molecular target for novel treatment strategies for nasal polyposis. However, there are still some potential limitations of this study, such as the small number of our experimental specimens; moreover, the experiment has not been verified by in vivo animal experiments, and allergic factors are also excluded from the experiment.

In summary, we demonstrated that miR-21 mediates TGF- $\beta 1$-induced EMT in PHNECs via the PTEN/Akt pathway. Our data indicate that TGF- $\beta 1$-induced EMT occurs during the pathogenesis of CRSwNP. Furthermore, we showed for the first time that the important role
miR-21 plays in TGF- $\beta 1$-induced EMT in CRSwNP. However, further studies are necessary to validate our hypothesis that miR- 21 mediates TGF- $\beta 1$-induced EMT, a key mechanism in the pathogenesis of CRSwNP, and, if so, whether targeting miR-21 could provide a new therapeutic strategy against CRSwNP in the future.

\section{Acknowledgment}

The authors thank the patients and their families. We thank all the members of the Department of Otolaryngology, Head and Neck Surgery of the Second Xiangya Hospital, Central South University, for their invaluable help.

\section{Statement of Ethics}

Subjects (or their parents or guardians) have given their written informed consent. The study protocol has been approved by the research institute's committee on human research.

\section{Disclosure Statement}

The authors have no conflicts of interest to declare.

\section{Funding Sources}

The study has no funding sources.

\section{References}

1 Fokkens WJ, Lund VJ, Mullol J, Bachert C, Alobid I, Baroody F, et al. EPOS 2012: European position paper on rhinosinusitis and nasal polyps 2012. A summary for otorhinolaryngologists. Rhinology. 2012 Mar;50(1):1-12.

2 Van Bruaene N, Bachert C. Tissue remodeling in chronic rhinosinusitis. Curr Opin Allergy Clin Immunol. $2011 \mathrm{Feb} ; 11(1): 8-11$.

3 Al-Muhsen S, Johnson JR, Hamid Q. Remodeling in asthma. J Allergy Clin Immunol. 2011 Sep;128(3):451-62.

$4 \mathrm{Kim} \mathrm{TH}$, Lee JY, Lee HM, Lee SH, Cho WS, Ju $\mathrm{YH}$, et al. Remodelling of nasal mucosa in mild and severe persistent allergic rhinitis with special reference to the distribution of collagen, proteoglycans, and lymphatic vessels. Clin Exp Allergy. 2010 Dec;40(12):1742-54.

5 Molet SM, Hamid QA, Hamilos DL. IL-11 and IL-17 expression in nasal polyps: relationship to collagen deposition and suppression by intranasal fluticasone propionate. Laryngoscope. 2003 Oct;113(10):1803-12.
6 Serpero L, Petecchia L, Sabatini F, Giuliani M, Silvestri M, Di Blasi P, et al. The effect of transforming growth factor (TGF)-betal and (TGF)-beta2 on nasal polyp fibroblast activities involved upper airway remodeling: modulation by fluticasone propionate. Immunol Lett. 2006 May;105(1):61-7.

7 Lazard DS, Prulière-Escabasse V, Papon JF, Escudier E, Coste A. [Injury and epithelial wound healing: a pathophysiologic hypothesis for nasal and sinus polyposis]. Presse Med. 2007 Jul-Aug;36(7-8):1104-8.

8 Mastruzzo C, Greco LR, Nakano K, Nakano A, Palermo F, Pistorio MP, et al. Impact of intranasal budesonide on immune inflammatory responses and epithelial remodeling in chronic upper airway inflammation. J Allergy Clin Immunol. 2003 Jul;112(1):37-44.
9 Wang QP, Escudier E, Roudot-Thoraval F, Abd-Al Samad I, Peynegre R, Coste A. Myofibroblast accumulation induced by transforming growth factor-beta is involved in the pathogenesis of nasal polyps. Laryngoscope. 1997 Jul;107(7):926-31.

10 Burgel PR, Escudier E, Coste A, Dao-Pick T, Ueki IF, Takeyama K, et al. Relation of epidermal growth factor receptor expression to goblet cell hyperplasia in nasal polyps. J Allergy Clin Immunol. 2000 Oct;106(4):70512.

11 Thiery JP. Epithelial-mesenchymal transitions in tumour progression. Nat Rev Cancer. 2002 Jun;2(6):442-54.

12 Lee HM, Kang JH, Shin JM, Lee SA, Park IH Chemical Chaperone of Endoplasmic Reticulum Stress Inhibits Epithelial-Mesenchymal Transition Induced by TGF- $\beta 1$ in Airway Epithelium via the $\mathrm{c}$-Src Pathway. Mediators Inflamm. 2017;2017:8123281.
TGF- $\beta 1$ Induces EMT of Chronic Sinusitis with Nasal Polyps via miR-21
Int Arch Allergy Immunol 2019;179:304-319 DOI: $10.1159 / 000497829$ 
13 Hupin C, Gohy S, Bouzin C, Lecocq M, Polette M, Pilette C. Features of mesenchymal transition in the airway epithelium from chronic rhinosinusitis. Allergy. 2014 Nov; 69(11):1540-9.

14 Shin HW, Cho K, Kim DW, Han DH, Khalmuratova R, Kim SW, et al. Hypoxia-inducible factor 1 mediates nasal polypogenesis by inducing epithelial-to-mesenchymal transition. Am J Respir Crit Care Med. 2012 May; 185(9):944-54.

15 Park IH, Kang JH, Shin JM, Lee HM. Trichostatin A Inhibits Epithelial Mesenchymal Transition Induced by TGF- $\beta 1$ in Airway Epithelium. PLoS One. 2016 Aug; 11(8):e0162058.

16 Balsalobre L, Pezato R, Perez-Novo C, Alves MT, Santos RP, Bachert C, et al. Epithelium and stroma from nasal polyp mucosa exhibits inverse expression of TGF- $\beta 1$ as compared with healthy nasal mucosa. J Otolaryngol Head Neck Surg. 2013 Apr;42(1):29.

17 Könnecke M, Burmeister M, Pries R, Böscke $\mathrm{R}$, Bruchhage KL, Ungefroren $\mathrm{H}$, et al. Epithelial-Mesenchymal Transition in Chronic Rhinosinusitis: Differences Revealed Between Epithelial Cells from Nasal Polyps and Inferior Turbinates. Arch Immunol Ther Exp (Warsz). 2017 Apr;65(2):157-73.

18 Elovic A, Wong DT, Weller PF, Matossian $\mathrm{K}$, Galli SJ. Expression of transforming growth factors-alpha and beta 1 messenger RNA and product by eosinophils in nasal polyps. J Allergy Clin Immunol. 1994 May; 93(5):864-9.

19 Zaravinos A, Soufla G, Bizakis J, Spandidos DA. Expression analysis of VEGFA, FGF2, TGFbeta1, EGF and IGF1 in human nasal polyposis. Oncol Rep. 2008 Feb;19(2):38591.

20 Yamin M, Holbrook EH, Gray ST, Busaba NY, Lovett B, Hamilos DL. Profibrotic transforming growth factor beta 1 and activin A are increased in nasal polyp tissue and induced in nasal polyp epithelium by cigarette smoke and Toll-like receptor 3 ligation. Int Forum Allergy Rhinol. 2015 Jul; 5(7):573-82.

21 Meng J, Zhou P, Liu Y, Liu F, Yi X, Liu S, et al. The development of nasal polyp disease involves early nasal mucosal inflammation and remodelling. PLoSOne.2013 Dec;8(12):e82373.

22 Zhang N, Van Zele T, Perez-Novo C, Van Bruaene N, Holtappels G, DeRuyck N, et al. Different types of T-effector cells orchestrate mucosal inflammation in chronic sinus disease. J Allergy Clin Immunol. 2008 Nov;122 (5):961-8.

23 Van Bruaene N, Derycke L, Perez-Novo CA, Gevaert P, Holtappels G, De Ruyck N, et al. TGF-beta signaling and collagen deposition in chronic rhinosinusitis. J Allergy Clin Immunol. 2009 Aug; 124:253-9, 251-9.

24 Yang Y, Zhang N, Lan F, Van Crombruggen K, Fang L, Hu G, et al. Transforming growth factor-beta 1 pathways in inflammatory airway diseases. Allergy. 2014 Jun;69(6):699-707.
25 Friedman RC, Farh KK, Burge CB, Bartel DP. Most mammalian mRNAs are conserved targets of microRNAs. Genome Res. 2009 Jan; 19(1):92-105.

26 Malizia AP, Wang DZ. MicroRNAs in cardiomyocyte development. Wiley Interdiscip Rev Syst Biol Med. 2011 Mar-Apr;3(2):183-90.

27 Stefani G, Slack FJ. Small non-coding RNAs in animal development. Nat Rev Mol Cell Biol. 2008 Mar;9(3):219-30.

28 Ambros V. The evolution of our thinking about microRNAs. Nat Med. 2008 Oct;14(10): 1036-40.

29 Li YF, Jing Y, Hao J, Frankfort NC, Zhou X, Shen B, et al. MicroRNA-21 in the pathogenesis of acute kidney injury. Protein Cell. 2013 Nov;4(11):813-9.

30 Esquela-Kerscher A, Slack FJ. Oncomirs - microRNAs with a role in cancer. Nat Rev Cancer. 2006 Apr;6(4):259-69.

31 Hergenreider E, Heydt S, Tréguer K, Boettger T, Horrevoets AJ, Zeiher AM, et al. Atheroprotective communication between endothelial cells and smooth muscle cells through miRNAs. Nat Cell Biol. 2012 Feb; 14(3):249-56.

32 Cao W, Shi P, Ge JJ. miR-21 enhances cardiac fibrotic remodeling and fibroblast proliferation via CADM1/STAT3 pathway. BMC Cardiovasc Disord. 2017 Mar;17(1):88.

33 Zhong X, Chung AC, Chen HY, Meng XM, Lan HY. Smad3-mediated upregulation of miR-21 promotes renal fibrosis. J Am Soc Nephrol. 2011 Sep;22(9):1668-81.

34 Ong J, Timens W, Rajendran V, Algra A, Spira $A$, Lenburg ME, et al. Identification of transforming growth factor-beta-regulated microRNAs and the microRNA-targetomes in primary lung fibroblasts. PLoS One. 2017 Sep;12(9):e0183815.

35 Lu TX, Munitz A, Rothenberg ME. MicroRNA-21 is up-regulated in allergic airway inflammation and regulates IL-12p35 expression. J Immunol. 2009 Apr;182(8):49945002.

36 Liu Y, Yang K, Shi H, Xu J, Zhang D, Wu Y, et al. MiR-21 modulates human airway smooth muscle cell proliferation and migration in asthma through regulation of PTEN expression. Exp Lung Res. 2015;41(10):535-45.

37 Liu Z, Wang J, Guo C, Fan X. microRNA-21 mediates epithelial-mesenchymal transition of human hepatocytes via PTEN/Akt pathway. Biomed Pharmacother. 2015 Feb;69: 24-8.

38 He X, Xie J, Zhang D, Su Q, Sai X, Bai R, et al. Recombinant adeno-associated virus-mediated inhibition of microRNA-21 protects mice against the lethal schistosome infection by repressing both IL-13 and transforming growth factor beta 1 pathways. Hepatology. 2015 Jun;61(6):2008-17.

39 Zhu H, Luo H, Li Y, Zhou Y, Jiang Y, Chai J, et al. MicroRNA-21 in scleroderma fibrosis and its function in TGF- $\beta$-regulated fibrosisrelated genes expression. J Clin Immunol. 2013 Aug;33(6):1100-9.
40 Simone BA, Ly D, Savage JE, Hewitt SM, Dan $\mathrm{TD}$, Ylaya $\mathrm{K}$, et al. microRNA alterations driving acute and late stages of radiation-induced fibrosis in a murine skin model. Int J Radiat Oncol Biol Phys. 2014 Sep;90(1):44-52.

41 Liu Y, Li Y, Li N, Teng W, Wang M, Zhang Y, et al. TGF- $\beta 1$ promotes scar fibroblasts proliferation and transdifferentiation via up-regulating MicroRNA-21. Sci Rep. 2016 Aug;6(1): 32231.

42 Li C, Song L, Zhang Z, Bai XX, Cui MF, Ma LJ. MicroRNA- 21 promotes TGF- $\beta 1$-induced epithelial-mesenchymal transition in gastric cancer through up-regulating PTEN expression. Oncotarget. 2016 Oct;7(41):669897003.

43 Dai X, Fang M, Li S, Yan Y, Zhong Y, Du B. miR-21 is involved in transforming growth factor $\beta 1$-induced chemoresistance and invasion by targeting PTEN in breast cancer. Oncol Lett. 2017 Dec;14(6):6929-36.

44 Liu G, Friggeri A, Yang Y, Milosevic J, Ding Q, Thannickal VJ, et al. miR-21 mediates fibrogenic activation of pulmonary fibroblasts and lung fibrosis. J Exp Med. 2010 Aug; 207(8):1589-97.

45 Livak KJ, Schmittgen TD. Analysis of relative gene expression data using real-time quantitative PCR and the 2(-Delta Delta C(T)) Method. Methods. 2001 Dec;25(4): 402-8.

46 Thum T, Gross C, Fiedler J, Fischer T, Kissler S, Bussen M, et al. MicroRNA-21 contributes to myocardial disease by stimulating MAP kinase signalling in fibroblasts. Nature. 2008 Dec;456(7224):980-4.

47 Davis BN, Hilyard AC, Lagna G, Hata A. SMAD proteins control DROSHA-mediated microRNA maturation. Nature. 2008 Jul; 454(7200):56-61.

48 Zhang YE. Non-Smad pathways in TGF-beta signaling. Cell Res. 2009 Jan;19(1):128-39.

49 Kakkar R, Lee RT. Intramyocardial fibroblast myocyte communication. Circ Res. 2010 Jan; 106(1):47-57.

50 Kou W, Hu GH, Yao HB, Wang XQ, Shen Y, Kang HY, et al. Regulation of transforming growth factor- $\beta 1$ activation and expression in the tissue remodeling involved in chronic rhinosinusitis. ORL J Otorhinolaryngol Relat Spec. 2012;74(3):172-8.

51 Smith KA, Orlandi RR, Rudmik L. Cost of adult chronic rhinosinusitis: A systematic review. Laryngoscope. 2015 Jul;125(7):1547-56.

52 Border WA, Noble NA. Transforming growth factor beta in tissue fibrosis. $\mathrm{N}$ Engl J Med. 1994 Nov;331(19):1286-92.

53 Bassiouni A, Chen PG, Wormald PJ. Mucosal remodeling and reversibility in chronic rhinosinusitis. Curr Opin Allergy Clin Immunol. 2013 Feb;13(1):4-12.

54 Sobol SE, Fukakusa M, Christodoulopoulos P, Manoukian JJ, Schloss MD, Frenkiel S, et al. Inflammation and remodeling of the sinus mucosa in children and adults with chronic sinusitis. Laryngoscope. 2003 Mar;113(3): $410-4$. 
55 Hackett TL, Warner SM, Stefanowicz D, Shaheen F, Pechkovsky DV, Murray LA, et al. Induction of epithelial-mesenchymal transition in primary airway epithelial cells from patients with asthma by transforming growth factor-beta1. Am J Respir Crit Care Med. 2009 Jul;180(2):122-33.

56 Kalluri R, Neilson EG. Epithelial-mesenchymal transition and its implications for fibrosis. J Clin Invest. 2003 Dec;112(12):1776-84.

57 Schleimer RP. Immunopathogenesis of Chronic Rhinosinusitis and Nasal Polyposis. Annu Rev Pathol. 2017 Jan;12(1):331-57.

58 Kalluri R, Weinberg RA. The basics of epithelial-mesenchymal transition. J Clin Invest. 2009 Jun;119(6):1420-8.

59 Massagué J. TGF $\beta$ signalling in context. Nat Rev Mol Cell Biol. 2012 Oct;13(10):616-30.

60 Heldin $\mathrm{CH}$, Miyazono K, ten Dijke P. TGFbeta signalling from cell membrane to nucleus through SMAD proteins. Nature. 1997 Dec; 390(6659):465-71.

61 Ryu NH, Shin JM, Um JY, Park IH, Lee HM. Wogonin inhibits transforming growth factor $\beta 1$-induced extracellular matrix production via the $\mathrm{p} 38$ /activator protein 1 signaling pathway in nasal polyp-derived fibroblasts. Am J Rhinol Allergy. 2016 Jul;30(4):128-33.
62 Hills CE, Squires PE. The role of TGF- $\beta$ and epithelial-to mesenchymal transition in diabetic nephropathy. Cytokine Growth Factor Rev. 2011 Jun;22(3):131-9.

63 Wang JY, Gao YB, Zhang N, Zou DW, Wang $\mathrm{P}$, Zhu ZY, et al. miR-21 overexpression enhances TGF- $\beta 1$-induced epithelial-to-mesenchymal transition by target smad7 and aggravates renal damage in diabetic nephropathy. Mol Cell Endocrinol. 2014 Jul;392(1-2):16372.

64 Liu ZL, Wang H, Liu J, Wang ZX. MicroRNA-21 (miR-21) expression promotes growth, metastasis, and chemo- or radioresistance in non-small cell lung cancer cells by targeting PTEN. Mol Cell Biochem. 2013 Jan; 372(1-2):35-45.

65 Bao L, Yan Y, Xu C, Ji W, Shen S, Xu G, et al. MicroRNA-21 suppresses PTEN and hSulf-1 expression and promotes hepatocellular carcinoma progression through AKT/ERK pathways. Cancer Lett. 2013 Sep;337(2):226-36.

$66 \mathrm{Zhu}$ W, Xu B. MicroRNA-21 identified as predictor of cancer outcome: a meta-analysis. PLoS One. 2014 Aug;9(8):e103373.

67 Li J, Jiang K, Zhao F. Icariin regulates the proliferation and apoptosis of human ovarian cancer cells through microRNA-21 by targeting PTEN, RECK and Bcl-2. Oncol Rep. 2015 Jun;33(6):2829-36.
68 Kalogirou C, Schäfer D, Krebs M, Kurz F, Schneider A, Riedmiller H, et al. MetforminDerived Growth Inhibition in Renal Cell Carcinoma Depends on miR-21-Mediated PTEN Expression. Urol Int. 2016;96(1):106-15.

69 Meng F, Henson R, Wehbe-Janek H, Ghoshal K, Jacob ST, Patel T. MicroRNA-21 regulates expression of the PTEN tumor suppressor gene in human hepatocellular cancer. Gastroenterology. 2007 Aug;133(2):647-58.

$70 \mathrm{Li} \mathrm{J}$, Yen C, Liaw D, Podsypanina K, Bose S, Wang SI, et al. PTEN, a putative protein tyrosine phosphatase gene mutated in human brain, breast, and prostate cancer. Science. 1997 Mar;275(5308):1943-7.

71 Bakin AV, Tomlinson AK, Bhowmick NA, Moses HL, Arteaga CL. Phosphatidylinositol 3-kinase function is required for transforming growth factor beta-mediated epithelial to mesenchymal transition and cell migration. J Biol Chem. 2000 Nov;275(47):36803-10.

72 Lamouille S, Derynck R. Cell size and invasion in TGF-beta-induced epithelial to mesenchymal transition is regulated by activation of the mTOR pathway. J Cell Biol. 2007 Jul; 178(3):437-51.

73 Thiery JP. Epithelial-mesenchymal transitions in development and pathologies. Curr Opin Cell Biol. 2003 Dec;15(6):740-6. 